УДК 2:27; 34:341; 32:322

\section{Ekaterina Elbakian}

\section{Religious diversity as a factor in public security}

Abstract. The article deals with topical issues of religious diversity in the framework of the religious situation in modern Russia.

The article analyzes important indicators of the religious situation. They include public sentiments created by the subjective perception of the country's population of their religiosity and non-religiousness, in the context of the realization of the freedom of conscience right.

Additional indicators of the religious situation are the following: inter-religious, inter-denominational relations and relations between believers and non-believers; the state and nature of public opinion in relation to religion.

The criteria for the "complexity» of a religious situation have been determined through delineating of 1) internal and 2) external circumstances that create the conditions for the tension of the religious situation. The first group (1) includes: the degree of satisfaction / dissatisfaction of believers and groups of believers with the implementation, provision and protection of their rights and interests; instability and unsettledness of inter-religious and ethnoreligious relations; the presence of contradictions and conflicts within religious associations. The second group (2) includes: the condition of state-religious relations associated with the implementation of legislatively enshrined principles and norms in the sphere of freedom of conscience by state and local authorities [Academic research]; the degree of mutual trust, loyalty, law-abidingness of religious associations; the state of public opinion in relation to religion, its adequate / inadequate expression by the media; the presence of conflicts between believers and non-believers, as well as the nature and intensity of missionary activities of religious organizations.

The examination of the religious situation, its comprehensive and objective analysis, serve as the basis for informational support of statereligious relations and as help in the implementation of the principles of the state's religious policy in the practical activities of the authorities and administration.

Using the example of a number of religious organizations, it will be shown that their persecution, especially of religious minorities, does not strengthen the security of the country, but, on the contrary, creates a number of quite serious risks for the stable functioning of society both «inside» the state and internationally. Considered through the prism of various models of state-religious relations, the religious situation in the country seems to be most favorable (both for the state and for religious organizations of various types) when there is religious freedom and the corresponding state-religious relations.

Key words: Russia, religion, state, security, multi-denaminationalism, society, risks.

\section{Катерина Елбакян}

\section{Релігійне різноманіття як фактор суспіљної безпеки}

Анотація. У статті розглянуто актуальні проблеми релігійного багатоманіття в рамках релігійної ситуації в сучасній Росії. 
Проаналізовано важливі показники релігійної ситуації. До них віднесені суспільні настрої, обумовлені суб'єктивним сприйняттям населення країни своєї релігійності і нерелігійності, в контексті реалізації права на свободу совісті.

Серед додаткових показників релігійної ситуації виділяються наступні: міжрелігійні, міжконфесійні відносини і відносини між віруючими і невіруючими; стан і характер громадської думки по відношенню до релігії.

Визначено критерії «складності» релігійної ситуації, через вичленення внутрішніх і зовнішніх обставин, які обумовлюють напруженість релігійної ситуації. До перших віднесені: ступінь задоволеності / незадоволеності віруючих і їх об'єднань реалізацією, забезпеченням і захистом їx прав та інтересів; нестабільність та неврегульованість міжрелігійних та етнорелігійних відносин; наявність протиріч i конфліктів всередині релігійних об'єднань.

До других віднесені: стан державнорелігійних відносин, пов'язаний 3 реалізацією органами державної влади та місцевого самоврядування законодавчо закріплених принципів і норм у сфері свободи совісті; ступінь взаємної довіри, лояльності, законослухняності релігійних об'єднань; стан громадської думки щодо релігії, його адекватне / неадекватне вираження за-собами масової інформації; наявність конфліктів між віруючими i невіруючими, а також характер i інтенсивність місіонерської діяльності релігійних організацій.

Дослідження релігійної ситуації, ï всебічний і об'єктивний аналіз $є$ основою для інформаційного забезпечення держав- но-релігійних відносин і допомогою в реалізації принципів віросповідної політики держави в практичній діяльності органів влади та управління.

На прикладі ряду релігійних організацій показано, що їх переслідування, особливо релігійних меншин, не зміцнює безпеку країни, а, навпаки, створює ряд досить серйозних ризиків для стабільного функціонування соціуму як «всередині» держави, так і на міжнародній арені. Розглянута через призму різних моделей державно-релігійних відносин, релігійна ситуація в країні $€$ найбільш сприятливою (i для держави, і для релігійних організацій різних типів), коли існує релігійна свобода i відповідні їй державно-релігійні відносини.

Ключові слова: Росія, релігія, держава, безпека, багатоконфесійність, сощіум, ризики.

Introduction to the problematic. Russia has never been a mono-denominational country. Today, as a result of the processes of globalization, mono-denominational countries are almost gone. Therefore, issues related to religious freedom and the corresponding statereligious relations are in the focus of religious studies scholars, lawyers, sociologists, philosophers, they are discussed at international conferences, they are highlighted in reports and articles by such researchers as I. Aslanova, V. Yelensky, Zagrebina I., Clark E., Podoprigora R., Pchelintsev A., O. Sibireva, Simkin L., Sitnikov M., Tytarenko V., Ferrari S., Fylypovych L., etc.

Most modern states are polydenominational in one way or another, for on their territory there are several or even several dozens (as in the case of Russia) religious groups and tens of thousands of registered 
religious organizations. Their functioning, relationships among themselves, as well as with society and the state as the political system of society, largely determine what we call the religious situation.

The purpose of this article is to examine the religious situation and its structure in the context of the implementation of religious freedom. The tasks of the article include: a) characterization of the religious situation, definition of internal and external circumstances that determine the tensions of the religious situation; b) analysis of specific examples of «extremism» defined as «religious» in the legal field of Russia; c) NRM (new religious movements) and the problems of their functioning in society, etc.

The main presentation of the material. What is a «religious situation» and what are its parameters? As it is known, a religious situation is a state of society coupled with the religiosity of its population [The concept of a religious situation]. The following researchers also write about this: Leshchinsky A., Sgibneva O., Stetskevich M., Shakhnovich M. The religious situation reflects the presence, nature, and intensity of religious manifestations, the dynamics and direction of their changes, the nature and extent of their impact on society. Therefore, it includes the characteristics of not only religious facts but also those social phenomena that, while not being religious by their nature, are somehow connected with religion.

The important indicators of the religious situation that need to be assessed at the level of mass consciousness are public sentiments related to the subjective feelings of the religious and non-religious population regarding compliance and full realization of the freedom of conscience right by believers and non- believers and the degree of satisfaction of the religious needs of believers - their legal and material support.

The next additional marker of the religious situation in the aspect of mass consciousness will be the state of relations between believers and non-believers, as well as between followers of different religious trends.

Another sign specifying the idea of a religious situation at the level of mass consciousness is the state and nature of public opinion in relation to religion in general and its particular areas.

The criteria for the «complexity» of a religious situation are the presence of contradictions in the religious sphere of society's life activities, as well as the degree of effectiveness of their resolution by state and administrative authorities. The circumstances that cause the tension of the religious situation from within can be:

-the degree of satisfaction/ dissatisfaction of believers and their associations with the realization, provision, and protection of their rights and interests;

- instability and unsettledness of interreligious and ethnoreligious relations;

- the presence of contradictions and conflicts within religious associations.

The external circumstances contributing to the worsening of the tension of the religious situation include:

- the condition of state-religious relations associated with the implementation by the state and local authorities of the legislatively established principles and norms in the sphere of religious freedom; - the degree of mutual trust, loyalty, compliance of religious associations;

- state of public opinion regarding religion, its adequate/inadequate expression by the media; 
- the existence of conflicts between believers and non-believers, as well as the nature and intensity of missionary activities of religious organizations.

Thus, the study of the religious situation, its comprehensive and objective analysis, can serve as the basis for the informational support of state-religious relations and substantial assistance in the implementation of the principles of religious policy of the state in the practice of the authorities and administration. Assessing the religious situation, one should consider the presence in the society or a region of various religious trends, consider their quantitative ratio and the relationship between them, their true integration into the given community or region, the relationship with this society and its constituent groups including ethnocultural and ethnoreligious. Further, it is necessary to have reliable data on the number of religious associations and according to religious traditions. Further, it is necessary to have reliable data on the number of religious associations in general and their distribution according to religious traditions. Moreover, it is essential to have information about the actual number of their followers and the level of their religiosity, i.e. reliable percentage of believers of the total population.

Religious situation is always evaluated at a particular (given) timepoint. However, in order to understand its developmental tendencies, it is necessary to compare it with the previous case, which helps to see the direction and characteristic features of its change.

The situation of religious minorities and its impact on the religious situation. In our opinion, religious minorities, in many respects, are a litmus paper, reflecting the real religious situation in any country and its regions.

If religious minorities feel stable, calm, comfortable, then the religious situation in the country is stable and conflict-free. If there is discrimination against religious minorities, this situation becomes unstable and even explosive, which in turn creates a threat to public security in general.

Earlier in the text it was already mentioned that if there is freedom of religion in the country, then it will be provided in all religious spheres - from the largest traditional religions to religious minorities, and if not, then it will not be granted to any religious organization. As a result, not only religious minorities, but also traditional religions will suffer from «religious captivity», for there will be a twofold process firstly, the suppression or liquidation of religious minorities; secondly, merging with the authorities and, therefore, loss of independence by major religious areas or one of them. Unfortunately, confirmation of how realistic this thesis is can be observed today on the example of the religious situation in Russia. Suppression or liquidation of religious minorities - in particular, liquidation of Jehovah's Witnesses' organizations, depriving the Church of Scientology of the religious status, the so-called "Yarovaya-Ozerov» amendments, which impose significant restrictions on missionary activity - the most important component of religious activities of the overwhelming majority of religious, especially Christian, organizations. The result of this «law experiment» was many lawsuits related to missionary activities, for example, Pentecostals. At the same time, despite the explanation of the Constitutional Court of the Russian Federation, which contains quite clearly formulated signs of missionary work, we must note extraordinary situations and inadequate accusations.

For example, in Nizhny Novgorod, an international student from Zimbabwe, Kudzai 
Nyamarevu, a member of the Pentecostal religious organization, Jesus Embassy, was charged with missionary work, which she did not do at all. The question was about her deportation from the country, although Kudzai was in her last year at the Medical Academy and had to get a medical degree in a few months. Kudzai's missionary activity was based on her repost from a girl who had problems with digestion and who thanked God that she managed to overcome these problems («I made a repost from the group» Vkontakte», in which my friend told me about her problems with digestion and thanked God that $\mathrm{He}$ helped her with this problem» [The video file, 6.25-7.06 min.]. Such an accusation is unfounded because it considers the missionary activity in such a broad perspective and extrapolates it to any mention of divine intervention. It would be possible to blame all believers who follow, for example, religiously motivated food bans (on the use of alcohol, pork, drugs, tobacco, coffee, etc.), moral norms (a ban on extramarital sexual relations, having entertainment, inappropriate attitude to parents, etc.), since religious motivation dominates in a similar way of life. It would also be possible to accuse the believer's inherent hope of divine help in challenging moments of life and gratitude to the higher forces in the case of a favorable resolution of complex life conflicts. However, in world literature and in cinematography, which does not belong to the genre of missionary production, there are a lot of similar examples.

At the same time, today the Russian Orthodox Church (ROC) declares that «a community of video-blogger priests will appear in Russia... Video-blogger priests will be able to «hold joint meetings, coordinate their efforts and thus develop», Vakhtang Kipshidze, deputy head of the Synodal
Department for Church Relations with Society and the Media of the Russian Orthodox Church, told the Moscow Agency. The clergy will share how to «effectively conduct Orthodox missionary work in the format of video blogs». At the same time, bloggers from the church plan to meet both online and offline. Dozens of priests have their blogs in Russia, Kipshidze notes. However, it is possible that by creating a community there will be even more of them. «We need to help those people who feel they have the talents and abilities as video bloggers», - said the representative of the Moscow Patriarchate. Secular experts will be attracted to the training of priests: the initiative is also welcome if they want to talk about the church on their blogs.

The mentioned examples testify to the imbalance of the religious situation in the country and rather strong conflictogenity that can threaten public safety.

Another aspect of public safety mentioned above is the persecution of many religious organizations, especially religious minorities. In our opinion, this does not strengthen the security of the country, but, on the contrary, creates quite severe risks for the stable functioning of society both «inside» the state and in the international arena.

As noted earlier, if freedom of religion is provided in the country, it will be so for all religious organizations, and the state and society in their secure mode will be a blessing. Let us explain these interrelated theses.

If the state helps some large organizations to get rid of undesirable elements that find themselves in its «canonical territory» and are engaged in missionary activity, consequently, attracting Russian citizens to its ranks («religious minorities»), while proceeding from certain notions, they must be members of organizations of historical religions or, at least, 
sharing their ideological attitudes, they end up losing not only religious minorities whose activities in the country are getting worse, or under any pretext are prohibited, but lose the historical religions as well.

By becoming «debtors» of the state for its help in clearing the missionary field for them, such religious organizations inevitably lose not only moral and ideological sovereignty. Now they must support and justify all of the actions of the state, its institutions, even in what may contradict their doctrinal guidelines. At first glance, in the context of ensuring state security, such coherence may seem attractive. In reality, this is only the appearance of «good» and is a «time bomb»: for religious organizations, this is a loss of one's own identity and actual unification with the state (with a legal proclamation of separation), and for the state it's a dangerous situation with the formation of increased risks in the sacred-ideocratic sphere associated with legitimation-ideological functions and processes. It is necessary to see a strategic perspective and understand that believers (and in religious minorities, membership in which brings not good, but only problems for the social life of an individual, people believe not nominally, but really, sincerely and actively) will not become unbelievers overnight. On the contrary, external difficulties only strengthen people in faith - let us recall the mass of examples from the 1930s, when Orthodox priests, Muslim mullahs, Buddhist lamas, Jehovah's Witnesses, and representatives of other religious groups were sitting together in the camps. Even if the religious organization was closed, people did not stop believing - on the contrary, the number of such believers usually only increases.

It turns out that inept, short-sighted administration in the sphere of state-religious, social-religious relations creates an uncontrollable or poorly controlled trouble spot in the state itself, among its citizens, whose interests it is designed to protect.

Let us recall that all members of the NRM are Russian citizens. Moreover, for the most part law-abiding, paying taxes to the state, including for protection and not for persecution. As for non-compliant citizens who turned out to be members of NRM, in such situations responsibility for their actions lies with a specific citizen, regardless of his religious affiliation, which is not at all determined by the presence of offenses.

Specificity of NRM (new religious movements). One more point needs consideration. When we talk about the NRM and traditional religions, we should certainly understand that the phenomena of religious life present in them have significant differences, and it is impossible to transfer the signs of one tradition to another. It is equally reprehensible to change the evaluation criteria, i.e. make them dependent on the political and ideological context. If, for example, the Russian Orthodox Church is accused of being not a religious, but a social organization? After all, the foundations of the social concept/teaching of the ROC indicate that a considerable amount of non-cult activity, including social, is conducted in it. Alternatively would it be accused of being irreligious due to the absence of daily five-fold prayer (namaz) in her ritual practice? How would religious scholars act in this case - would they deny the right of being considered as religion, because, in this context, only Islam follows this prayer pattern? However, a conclusion on this subject from a qualified religious scholar would prove a religious status defense of the Russian Orthodox Church. 
NRM more often get into the field of attention of religious scholars only because more questions arise due to their otherness. They account for a higher number of unfounded claims and even attacks. If such attacks had taken place against major religious organizations and groups, the intensity and frequency of mentioning them, including those with signs of scandalousness, would have been higher.

Religious situation through the prism of models of state-religious relations. When considering the current religious situation in Russia through the prism of models of statereligious relations, the following picture will be revealed. Without examining certain nuances, there are three main models of state-religious relations:

- identificating, with a focus on monoconfessionalism and theocracy in one form or another, the existence of the state religion;

- cooperative, with a focus on multiconfessional; there is a differentiated approach to religious associations, religious associations have different levels of rights and obligations;

- separative, with a focus on polyconfessionalism, where the universal principle applies to religious associations when religious associations have equal rights and duties regardless of their religious affiliation.

The Constitution of the Russian Federation enshrines the separative model of statereligious relations. At the same time, in recent years there has been a situation of deviation from this model and drift towards the cooperative model when not all religions and religious organizations are equal under the law (as stated in the Constitutional Law of the country).
This situation creates many difficulties, since religious minorities, in the legal field, are characterized by their law-abidingness, are actively involved in social service, etc., but are exposed to visible or latent persecution. At the same time traditional religions appeal to the duration of their existence, incorporation into the socio-cultural context of the country, the number of members and the concept of «canonical territory». The result is that the former refers to the Constitution of the Russian Federation, and the latter to historical arguments.

Probably, the state is interested in bringing these two extremes to harmony. That is, all religious organizations recognized by the state should feel comfortable and, most importantly, the separation model stated in the Constitution should work, and not remain only declared.

In certain circles, an alternative opinion is expressed. They say that instead of not changing the Constitution (separation model), bringing the real religious policy in line with it and stabilizing the religious situation in line with the law, change the current Constitution of the Russian Federation. They say that instead of not changing the Constitution (separation model), bringing the real religious policy in line with it and stabilizing the religious situation legally, changing the current Constitution of the Russian Federation? That means getting in line with some unconstitutional tendencies, by introducing, instead of a separation model, a cooperative one with its unequal rights and obligations for different religious organizations.

However, there is a question: what could the latter lead to in the future? In our opinion - it will do no good. First, a departure from the principles of religious freedom can only be the first step toward a state religion. Consequently, all religious organizations in the country, 
including the ROC, will become completely unfree.

Majoritarian - from the will of secular politicians, and discriminated - from the possibility to be open, because of the loyalty of people to their religious beliefs, would have moved into the «religious underground».

Imputation of religious extremism as a way to combat objectionable religious trends. Today one of, if I may say so, and «effective» tools for fighting undesirable religious organizations is accusing them of extremism. Such an accusation, if confirmed by a court decision, entails, in addition to the closure of the LRO or the centralized religious organization, the alienation of its property, including buildings, in favor of the state.

Although this is a separate topic, I would like to briefly note, based on the experience of participating as an expert in such trials, that the concept of extremism in Russian legislation (articles of the Criminal Code related to extremism 282, 280, 205, part 2. [The Criminal Code], 114-Ф3 «On Countering Extremism» [On countering extremism]) is very amorphous, viewed through the prism of the terms «hatred» and «enmity» undefined in the law, as well as the phrase «humiliation of dignity». The scope of these concepts is not limited to the definition, therefore, in principle, under them, with varying degrees of justification, it is possible to mention a lot of actions and attitudes in which this «extremism» can manifest itself. Thus, in 2010-2017, the number of causes imposed for extremist activity significantly increased. In 2017, 650 criminal causes for extremism and over 3 thousand administrative ones were issued [In 2017].

First, this refers to the «extremism», which is often defined as «religious». We know about a fairly large number of lawsuits related to the socalled. «Religious extremism», based primarily on expert (or, more precisely, «false expert») assessments of religious literature. The main claim to religious literature lies in meaningful statements regarding the truth of their own religion and the falsity of the rest or atheistic worldview. As a rule, in such cases, we are talking about the literature of religious minorities.

At the same time, the science of religion has long known that any religious consciousness divides the world into «own» and «alien», into «we» and «they». The fellow believers are among their «own», the rest of the world is among the «aliens». With varying degrees of emotional intensity, it is proclaimed that from soteriological and the eschatological perspective, only co-religionists have a chance for salvation. The rest of the world, «lying in sin» (because it does not share these beliefs), will perish. On such oppositions, as a rule, any religious discourse is built, and by this logic, any religious «work» is built, from a small oral sermon to an article or a voluminous book, and even sacral tests.

According to religious scholars and lawyers, the criterion for attributing an act or text to extremism is a direct call for violence. Concurrently, oral and written statements that are not accompanied by violence and do not directly appeal to it cannot be considered as crimes whose object is «the foundations of the constitutional system and state security».

Further, the phrase «Degrading the dignity of a person or a group of people», strictly speaking, is a civil-legal category that has nothing to do with extremism or extremist crimes, which is far from the fundamentals of the constitutional system and state security. 
The extremist sense of «superiority» should imply the superiority of a person over a person in the aspect of the existence and realization of his rights and freedoms, and not by a world outlook.

Extremism, understood as an attempt to radically and illegally solve some social (in a broad sense) tasks, is neither religious, nor racial, nor national. At the same time, religious, racial or national identity can be used by extremists for their purposes. Extremism can be hidden behind certain forms - religious, ethnic, national, but, as you know, «the map is not the territory» (N. Smart). Also, the essence of extremism remains the same, regardless of which images and symbols it appeals to and uses to justify unlawful actions. That is, it remains extremist, stemming from the sociopolitical and economic context in which extremist actions take place.

Conclusion that follows from the above material is the following: the religious situation in the country seems to be most favorable for the state, various religious organizations and society as a whole when religious freedom really exists. That is, when state-religious relations based on the principles of religious freedom are not only declared, but also implemented in real life.

Let us also emphasize the importance of realizing the following fact that if we are talking about NRM and historical religions, we must certainly understand that the phenomena of religious life recorded in them have significant differences, and it is impossible to transfer the signs of one tradition to another. It is equally reprehensible to change the evaluation criteria, i.e. make them dependent on the political and ideological context.

\section{References}

Academic research and conceptualization of religion in the XXI century: traditions and new challenges. Collection of materials of the Third Congress of Russian Researchers of Religion (7 - 9.10.2016, Vladimir, VISU) In six volumes. Volume 4. URL: https:/ / religiousstudies.in/wpcontent/uploads/2016/10/Kongress-Tom-4.pdf

In 2017, there were more sentences for extremism and fewer for corruption. Russian judges announced statistics on the most controversial cases. Express newspaper. (2018, February 20). URL: https://www.eg.ru/society/471928

Leshchinsky, A.N. The religious situation in modern Russia: changes, trends, contradictions URL: https:/ / rusoir.ru/03print/03print01/03print-01-25/

On countering extremism. FZ-114 (2002, July 25) URL: http://era-group-spb.ru/en/lawfed4/

Sgibneva, O. I. The religious situation: the main parameters of the study. URL:

https:/ / religious.life/2016/02/sgibnevareligioznaya-situatsiya-osnovnye-parametryissledovaniya/

Stetskevich, M.S., Shakhnovich M.M. The religious situation in modern Russia. URL:

https://voluntary.ru/termin/religioznajasituacija.html

The concept of missionary activity of the Russian Orthodox Church. URL:

http://azbyka.ru/katehizacija/kontseptsijamissionerskoj-dejatelnosti-russkoj-pravoslavnojtserkvi.shtml

The concept of a religious situation and its features in the modern world. URL: http:/ / www.christianweb.ru/study-302-1.html

The Criminal Code of the Russian Federation. URL: http:/ / rulaws.ru/uk/?yclid=18192977768831278352

The video file "Interview with Kuzai Nyamarebvu.mp4" (Created on 2018, May 1) at 16 hours 44 minutes, size 92872615 bytes 


\section{Список літератури}

Академическое исследование и концептуализация религии в XXI веке: традиции и новые вызовы. Сборник материалов Третьего конгресса российских исследователей религии (7 9.10.2016, Владимир, ВлГУ) В шести томах. Том 4. URL: https://religiousstudies.in/wpcontent/uploads/2016/10/Kongress-Tom-4.pdf

В 2017 году стало больше приговоров за экстремизм и меньще за коррупиию. Российские судьи огласили статистику по самым спорным делам. Экспресс газета. (2018, Февраль 2018). URL: https://www.eg.ru/society/471928

Видеофайл «Интервъю с Кудзай Нямаребву.тр4». (Создан 2018, Май 1) г. в 16 ч. 44 мин., размером 92872615 байт

Конщепция миссионерской деятельности Русской православной церкви. URL:

http://azbyka.ru/katehizacija/kontseptsijamissionerskoj-dejatelnosti-russkoj-pravoslavnojtserkvi.shtml

Лещинский, А.Н. Религиозная ситуация $b$ современной России: изменения, тенденции, противоречи. URL:

https:/ / rusoir.ru/03print/03print-01/03print-0125/

О противодействии экстремизму. Ф3-114 (От 2002, Июль 25). URL: http:/ / era-groupspb.ru/ru/lawfed4/

Понятие религиозной ситуации и ее особенности $b$ современном мире. URL: http:/ / www.christianweb.ru/study-302-1.html

Сгибнева, О.И. Религиозная ситуация: основные параметры исследования. URL:

https:/ / religious.life/2016/02/sgibneva-

religioznaya-situatsiya-osnovnye-parametryissledovaniya/

Стецкевич, М.С., Шахнович, М.M. Религиозная ситуация в современной России. URL:

https://voluntary.ru/termin/religioznajasituacija.html

Уголовный кодекс Российской Федерации. URL: http:/ / rulaws.ru/uk/ ?yclid=1819297776883127835 